\title{
建設残土の有効利用のための土量配分計画モデル \\ SOIL ALLOCATION MODELS FOR UTILIZATION OF SURPLUS SOIL IN CONSTRUCTION WORKS
}

\author{
見波 潔*・嶋 津晃臣** \\ By Kiyoshi MINAMI and Akiomi SHIMAZU
}

\begin{abstract}
Although enormous volume of soil is excavated and discharged from construction works, disposal sites for the surplus soil decrease in urban area year by year. With this point as background, it is desirable to establish soil recycling system, that is effective utilization of soil between construction sites where surplus soil is discharged and other sites where soil is used as material for embankment, landfill, etc. In this study, three models for soil allocation are proposed corresponding to certainty of input data. (1) Model $I$ is based on presupposition that all the relevant data are known deterministically. (2) Model II determines proper soil allocation in consideration of adjustment of working time on condition that input data for start time of each construction work has uncertainty. (3) Model III determines proper matches of construction works from the viewpoint of effective utilization of surplus soil.

Keywords : discharged soil, earthwork planning, soil allocation, linear programming, fuzzy programming
\end{abstract}

\section{1.はじめに}

土の掘削を伴う建設工事からは大量の掘削土が残土と して場外搬出されている．従来から残土の多くは臨海部 の埋立て地もしくは内陸処分地に運ばれて処分されてい るが，埋立て計画にも自ずから限界があり，また環境問 題等の理由から内陸処分地の確保も非常に困難になって いる.このため, 都市圏では残土処理が建設工事遂行上 の大きな問題となっている.

一方, 土を利用する工事 (道路等の盛土工事, 土地造 成工事，埋戻し工事など）の側をみると，従来から土は 各種の土木材料の中でも比較的安価で入手も容易な材料 とされていたが，近年になって良質な山砂資源の保護に 対する関心の高まりや，土取場の遠隔化に伴う土砂運搬 費の上昇などの理由から，土は必ずしも安価で入手しや すい材料とはいえず，土の入手先の確保にも困難を伴う 状況となっている.

このような問題に対処するために，残土を“処分”す るというこれまでの考え方から，残土を資源として“有

* 正会員 工修 建設省東北地方建設局道路部道路計画第二 課長 (T980 仙台市二日町 9-15)

** 正会員 工修 建設省土木研究所機械施工部長 ( ₹305 茨城県つくば市大字旭 1)
効利用 (以下，流用とよふ）”するという考え方への転 換の必要性が提唱されている ${ }^{1), 21}$. そのための具体的な 施策の 1 つとして, いくつかの大都市圏では土砂の搬出 入を伴う工事の予定を事前に収集し，そのリストを関係 機関に配布することによって流用の促進が図られてい る.これによって残土の流用がかなり行われるように なってきたものの, 実際に流用を行うかどうかは個々の 工事担当者の判断に委ねられているため, 残土の流用を 総合的かつ効率的に行うという段階に達しているとはい えない.

本研究は, 上述した残土問題を個々の工事レベルでの 問題としてではなく, 多くの建設工事を統括・調整する 立場に立って解決を図るべき問題としてとらえ, 複数工 事間の残土の流用を合理的に行うための土量配分計画乇 デルを提案するものである.土量配分計画では, 入力デー 夕をどの程度の確からしさで入手できるかによって計画 立案の考え方が異なると考えられることから, 本研究で は特に各工事の土工開始時期に関する入力情報に着目 し, その確からしさの程度に応じた 3 種類の計画モデル を提案する.

\section{2. 土量配分計画の基本的な考え方}

本稿で述べる土量配分計画とは, 残土を発生する複数 
の工事（以下，搬出工事之よぶ）から地盤・盛土用資源 として土を利用する複数の工事 (以下, 搬入工事とよぶ) への残土の合理的な流用計画をいう. 残土の流用が成立 するための条件は以下のように整理される.

(1) 搬出工事側と搬入工事側の流用土量が一致するこ と.

(2) 残土の土質が搬入工事側の土質条件を満たすこ 亡.

(3) 残土の発生時期と搬入工事側での利用時期が適合 すること.

これらの条件に加えて，残土の合理的な流用を行うた めには,

(4) 客観的な評価基準の下で残土の最適な流用先を決 定すること，

が必要である.

本研究では，これらの条件を考慮して土量配分計画問 題をモデル化した．すなわち，条件(1)については個々の 工事での土量条件をモデルの中に組み込んだ。条件(2)に ついては，後述するような土質分類を考慮することで対 処した。また，条件(3)については，計画対象期間を “期” に分割し，それぞれの期で条件(1)(2)を満足させることと した．また，ストックヤードを設けて搬出・搬入時期の 調整も考慮できるようにした。

条件(4)に関しては，どのような評価基準を設定するか が重要な問題となる．現時点で考えられる評価基準とし ては以下のようなものが挙げられよう.

評価基準 I : 総費用【(流用, 購入, 捨土時の土砂運 搬費 $)+$ (ストック費 $)+$ (土砂購入費 $)+$ (捨土処分費)】の最小化

評価基準 II : 総輸送量 【(運搬土量) $\times$ (運搬距離) 総和】の最小化

評価基準 III：総流用土量の最大化

評価基準 $\mathrm{V}$ : 土砂運搬距離の均衡化（工事間の土砂運 搬距離に大きなばらつきが生じないよ う, 最長運搬距離を最小化する)

いずれの指標を最適性の評価基準として設定するかは 高位の意志決定にかかわる問題であり, 残土問題に対す
る社会的なコンセンサスが形成される中で決定されるべ きものと考える. 土量配分計画問題はいずれの評価基準 を用いてもモデル化が可能であるが，本研究では経済性 の観点を重視するものとし，本稿では特に評価基準 I を 設定した場合についてのモデルを示すこととする.

\section{3. 土量配分計画モデルの概要}

土量配分計画を立案するにあたっては，一定期間内に 予定されている工事から排出される残土およびその受け 入れ可能性についての情報があらかじめ得られている必 要がある．表一1 は土量配分計画モデルへの入力情報の 種類を整理したものである.

本研究で提案する土量配分計画モデルはこれらの情報 が与件であることを前提としているが, 計画立案時点で これらの調査を行うと調査結果の精度に差違が生じ得る 之考えられる. 特に, 搬出工事, 搬入工事にかかわる項 目では，個々の工事計画が明確になっておれば「工事場 所」「土量」のデー夕はかなりの正確さで得ることがで きるが，「工事時期」に関するデータについては調查時 点によってはある程度の不確実性が含まれる可能性があ る.

そこで，本研究では「工事時期」に関するデータの不 確実性の程度に着目し，表一2に示す 3 種類の土量配分 計画モデルを考えた。

モデル I は，すべての入力情報が確定量として得られ る場合に適用されるもので，特定の評価基準の下で最適

表一1 土量配分計画モデルへの入力情報

\begin{tabular}{|c|c|}
\hline 対 & 入力情報の内容 \\
\hline 搬出工事 & $\begin{array}{l}\cdot \text { - 工事埸所 ·残土量 } \cdot \text { 土貿 } \\
\text { - 発生時期 }\end{array}$ \\
\hline 搬入工事 & 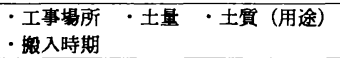 \\
\hline $\begin{array}{l}\text { 土質改良 } \\
\text { プラント }\end{array}$ & $\begin{array}{l}\text { - 設直場所 ・改良能力 ・改良費用 } \\
\text { ・プラント内のストック可能量 }\end{array}$ \\
\hline $\begin{array}{l}\text { ストック } \\
\text { ヤード }\end{array}$ & $\begin{array}{l}\text { ・場所 ・ストック費用 } \\
\text { ・ストック可能量 } \\
\end{array}$ \\
\hline 搭土処分 & 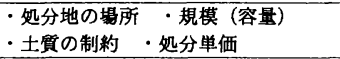 \\
\hline 土砂購入 & 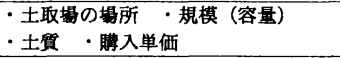 \\
\hline 搬 & 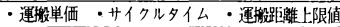 \\
\hline
\end{tabular}

表一2 土皇配分計画モデルの種類と特徴

\begin{tabular}{|c|c|c|c|c|}
\hline モ デルの璉 類 & 入力情報の特 徵 & 決 定 変 数 & 目 的 関 数 & 手 法 \\
\hline $\begin{array}{c}\text { モデル I : 土量配分計面モデル } \\
\text { (基本モデル) }\end{array}$ & $\begin{array}{l}\text { 表一 } 1 \text { に示す入力情報を確定量 } \\
\text { として与える。 }\end{array}$ & $\begin{array}{r}\mathrm{X}_{1}^{\dagger} \mathrm{j}: \text { 第 } \mathrm{t} \text { 期に搬出工事 } \mathrm{i} \text { から } \\
\text { 搬入工事 } j \text { へ運ばれる土量 }\end{array}$ & 総費用の最小化 & 線形計画法 \\
\hline $\begin{array}{r}\text { モデルII : 工期調整を考慮した } \\
\text { 土量配分計画モデル }\end{array}$ & $\begin{array}{l}\text { ·個々の工事の土工開始時期を } \\
\text { あいまいな情報として与える。 } \\
\text { ·総費用の志望水望を入力する。 }\end{array}$ & $\begin{array}{l}\text { (1) } X_{i j}^{t} \text { : 同 上 } \\
\text { (2)調整された土工開始時期 }\end{array}$ & $\begin{array}{l}\text { 土工開始時期およ } \\
\text { び総費用に関する } \\
\text { 懜属度の最大化 }\end{array}$ & $\begin{array}{l}\text { ファジィ線形 } \\
\text { 計画法 }\end{array}$ \\
\hline $\begin{array}{r}\text { モデルIII : 搬出・搬入工事の } \\
\text { 最適組合せモデル }\end{array}$ & $\begin{array}{l}\text { 值々の工事の土工開始時期を確 } \\
\text { 率的に与える。 }\end{array}$ & $\begin{aligned} \delta \mathrm{ij}: \text { 搬出工事 } \mathrm{i} \text { の残土を搬入 } \\
\text { 工事 } \mathrm{j} \text { へ流用するとき } 1 \text {. } \\
\text { そうでないとき0 }\end{aligned}$ & $\begin{array}{l}\text { 総費用の期待値の } \\
\text { 最小化 }\end{array}$ & $\begin{array}{l}0-1 \text { 型整数 } \\
\text { 線形計画法 } \\
\text { (割当て問題) }\end{array}$ \\
\hline
\end{tabular}


な土量配分を出力するものである.

モデル II は，個々の工事の開始時期に関する情報があ いまいな情報としてしか得られず，しかも各工事の土工 開始時期を一定の範囲内で調整することが可能な場合に 適用されるものである。このモデルでは，最適な土量配 分および各工事の調整された土工時期が出力される.

モデル III は，個々の工事の開始時期が確率的に与えら れる場合に適用され，特定の指標の期待値を評価基準之 して搬出工事と搬入工事の最適な組合せを出力するもの である、このモデルの場合, 工事の組合せのみを決定す るものであり，時期別の流用土量といった詳細な土量配 分は当該工事間の調整に委ねることになる.

以下では，各モデルの定式化および適用事例を示す.

\section{4. 入力情報が確定量として与えられる場合の 土量配分計画モデル (モデル I )}

\section{（1）基本モデルの概要}

残土の流用条件は 2. に述べたとおりであるが，この ような条件を満たす流用形態として次の 3 通りがある.

ア）搬出工事加搬入工事への直接の流用

イ） ストックヤードを介して搬出・搬入時期の調整 を行ったうえでの流用

ウ）土質改良プラントで土質改良を行い，残土の土 質と搬入工事側の土質条件を適合させたうえでの 再利用

これら 3 つの流用形態を考虑に入れて基本モデルを構 築した. モデル化にあたっての前提条件は次のとおりで ある。

i ） 表一1 に示した入力情報が確定量として与えられ るものとする.

ii）計画対象期間を $T$ 期に分割し, 各期の流用土量, 捨土処分量, 土取場からの購入量を決定変数とする.

iii）上記イ), ウ）の流用形態に関し，モデル中に複 数のストックヤードと土質改良プラントを組み込む ものとする。

iv）土質に関しては, “土質レベル”という概念で表 わすことにする．発生する残土の土質はあらかじめ 設定した土質分類に基づいて表示すればよいが，搬 入工事側での要求土質は用途に応じてある範囲を設 定することが多く，これを土質レベルという概念で 表わすことにした．すなわち，レベルの高い土質と は，搬入工事側での用途の広い土質を意味し，一般 には砂や碩などが想定される. 一方, レベルの低い 土質とは, 用途が限定される土質を意味し, 含水比 の高い粘性土などがこれに相当する. 土質レベルの 設定例を表一3に示す.

v）2.に述べた(1) (3)の流用条件をモデルの制約条

\begin{tabular}{|c|c|c|}
\hline 上賽レベル & 残 & 搬入下本での要求十䝿 \\
\hline$k=3$ & 榉、砂 & $\begin{array}{l}\text { 磷、砂、または同等の改 } \\
\text { 良土に限る。 }\end{array}$ \\
\hline $\mathrm{k}=2$ & 砂質土 & $\begin{array}{l}\text { 磁、砂、砂貿士、または } \\
\text { 同等の改良土に限る。 }\end{array}$ \\
\hline $\mathrm{k}=1$ & 粘性土 & $\begin{array}{l}\text { 砂、砂質土、站性土 } \\
\text { のいずれでもよい。 }\end{array}$ \\
\hline$k=0$ & $\begin{array}{l}\text { 含水此が高い } \\
\text { 泥土など }\end{array}$ & 一 \\
\hline
\end{tabular}

\begin{tabular}{|c|c|}
\hline 婄 号 & 定 \\
\hline$x_{i j}^{t}(k)$ & $\begin{array}{l}\text { 第 } \mathrm{t} \text { 期に搬出工事 } \mathrm{i} \text { から㮽入工事 } \mathrm{j} \text { へ流用される } \\
\text { 土筫レヘル } \mathrm{k} \text { の土量 }\left(\mathrm{m}^{2}\right)\end{array}$ \\
\hline $\mathrm{Y}_{\mathrm{ip}}^{\mathrm{t}}\left(\mathrm{k}, \mathrm{k}^{\prime}\right)$ & 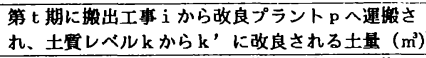 \\
\hline$\hat{\mathrm{Y}}_{\mathrm{pj}}^{\mathrm{t}}\left(\mathrm{k}^{\prime}\right)$ & 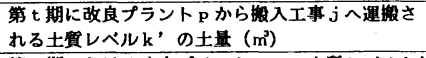 \\
\hline$u_{p}^{t}\left(k^{\prime}\right)$ & $\begin{array}{l}\text { 第 } \mathrm{t} \text { 期における改良プラントpでの土質レベル k } \\
\text { のストック土量 }\left(\mathrm{m}^{3}\right)\end{array}$ \\
\hline $\mathrm{z}_{\text {is }}^{\mathrm{t}}(\mathrm{k})$ & 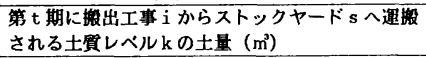 \\
\hline$\hat{\mathrm{z}}_{\mathrm{sj}}^{\mathrm{t}}(\mathrm{k})$ & $\begin{array}{l}\text { 第 } \mathrm{t} \text { 期にストックヤード } \mathrm{s} \text { から投入工事 } \mathrm{j} \text { 人運搬 } \\
\text { される土貿レベル } \mathrm{k} \text { の土量 }\left(\mathrm{m}^{\mathrm{m}}\right)\end{array}$ \\
\hline$q_{s}^{t}(k)$ & $\begin{array}{l}\text { 第 t 期におけるストックヤード } \mathrm{s} \text { での土質レベル } \\
\mathrm{k} \text { のストック土量 }\left(\mathrm{m}^{\mathrm{l}}\right) \\
\end{array}$ \\
\hline$D_{i d}^{t}(k)$ & $\begin{array}{l}\text { 第 } \mathrm{t} \text { 期に洀出工事 } \mathrm{i} \text { から処分地 } \mathrm{d} \text { へ指土処分され } \\
\text { る土貿レヘル } \mathrm{k} \text { の土量 }\left(\mathrm{m}^{3}\right)\end{array}$ \\
\hline$B_{b j}^{t}(k)$ & $\begin{array}{l}\text { 第 } \mathrm{t} \text { 期に土取堨 } \mathrm{b} \text { から搬入工事 } \mathrm{j} \text { へ搬入される土 } \\
\text { 貿レヘル } \mathrm{k} \text { の土量 }\left(\mathrm{m}^{3}\right)\end{array}$ \\
\hline
\end{tabular}

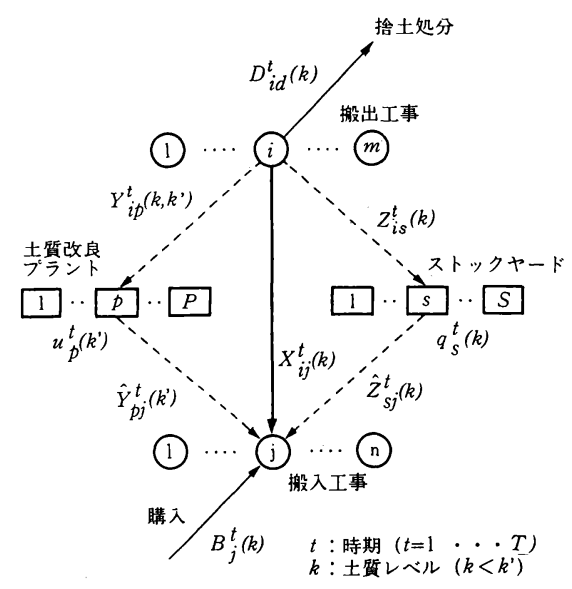

图一1 モデルの決定変数

件とし，総費用の最小化を目的関数とする．このう ち土質条件に関しては，「残土の土質レベルが搬入 工事側の要求土質レベルよりも高いこと」が流用が 成立するための必要条件となる。

以上の前提条件のもとで，土量配分計画モデルを線形 計画問題として定式化した．紙面の都合上, 定式化の詳 細は省略し, モデルの決定変数のみを表一 4 , 図一1に 示す。

(2) 適用事例

（1）に示した基本モデルでは，土質改良を施したう えでの再利用も考慮に入れているが，土質改良を行う工 
種は道路占用工事（管理設工事）などに限定され, 一般 の工事では土質改良を伴わない流用が主体となる，本稿 では，一般の工事を対象にした土量配分計画について述 ベることとし, 基本モデルから土質改良プラントに関す る項を除いてモデルを適用した例を示すことにする。な お，対象を道路占用工事に限定し，改良土の再利用を主 体とした土量配分計画に対して本モデルを適用した事例 については参考文献 3 ）を参照されたい.

a) 事例計算の対象

本モデルを $\mathrm{S}$ 県東南部 (東西 $25 \mathrm{~km}$, 南北 $35 \mathrm{~km}$ の 区域)の土量調查デー夕に対して適用した.この調查は, 次年度に予定されている搬出工事と搬入工事の場所, 工 事時期, 搬出・搬入土量, 土質などを毎年調べているも ので，その結果を土量調查リストにして関係機関に配布 し, 残土の流用促進を図っている. 本モデルにはこのよ うな土量調査データが入力されるわけであるが，一般に 県域レベルの広がりをもつ地域ではかなりの件数の工事 情報が収集され，工事規模（搬出・搬入土量）にもかな りのばらつきがみられる．調查されたすべての工事を同 時に考慮して本モデルを適用することは理論上は可能で あるが, 計算時間の面で必ずしも実際的とはいえない. そこで，計画作成のプロセスを図一2に示すように3つ のステップに分け，大規模工事から順次土量配分計画を 作成していくのが本モデルの現実的な適用方法と考元 る. 以下では,この 3 つのケースを想定してモデルを適 用した結果を示すことにする.

なお，本事例では計画対象期間を 1 年としており，こ れを 12 期に分割して 1 か月単位で工事時期のデータを 扱うことにした。 また，土質レベルについては表一3に 示した分類に従うこととした。

b) 計算結果

i ）大規模工事を対象にしたケース

ここでは搬出・搬入土量が 2 万 $\mathrm{m}^{3}$ 以上の工事を大規 模工事とし, 上述した土量調查りストの中から 19 件の 搬出工事 (総搬出土量 104 万 $\mathrm{m}^{3}$ ) と 20 件の搬入工事 (総 搬入土量 114 万 $\left.\mathrm{m}^{3}\right)$ を抽出した. モデルの適用にあたつ ては，残土を流用する際の般出・搬入工事間の距離の上 限をパラメーター $(10 \mathrm{~km}, 20 \mathrm{~km}, 30 \mathrm{~km})$ とするとと もに，対象地域のほぼ中央にストックヤードが有る場合 と無い場合を想定した．捨土処分費，土砂購入費につい ては現在の標準的な価格のほかに, 将来の高騰を想定し て 5 割増しの値を設定して試算を行った.

本モデルからは各期の流用土量 $X_{i j}^{t}(k)$ などが出力さ れるが，これをすべて図示することは紙面の都合上不可 能なので，ここでは総流用土量および総費用のみを示す ことにする. 図一3は，残土を流用する場合の工事間距 離の上限值をパラメーターとして総流用土量と総費用を

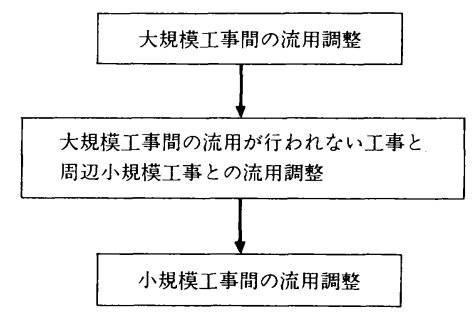

図一2 土量配分計画作成のプロセス
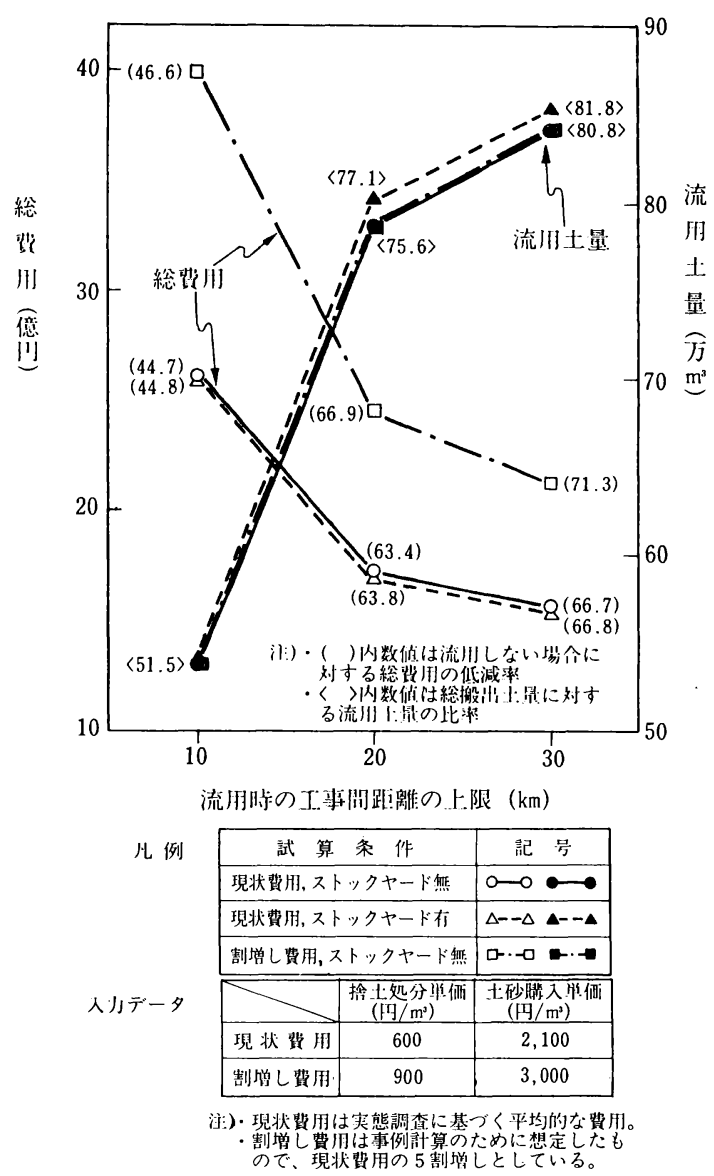

図一3 大規模工事へのモデルIの適用結果

示したものである.この図から，流用時の工事間距離に 関する制約を緩くするほど多量の流用が可能となり，こ れに伴って捨土処分量および土砂購入量が減少するため に総費用が大幅に低減されることがわかる．すなわち， 地域全体の土砂処分調達費の低減化という観点からみる と，できるだけ広い範囲で残土の流用調整を行う方が費 用効果が大きいといえる．特に，全く流用しない場合に 対する総費用の低減率をみてわかるように，大規模工事 間の残土流用による費用効果は非常に大きく，この結果 からも流用調整の重要性が認識される.

次に，ストックヤードの有無による差違をみると，こ 


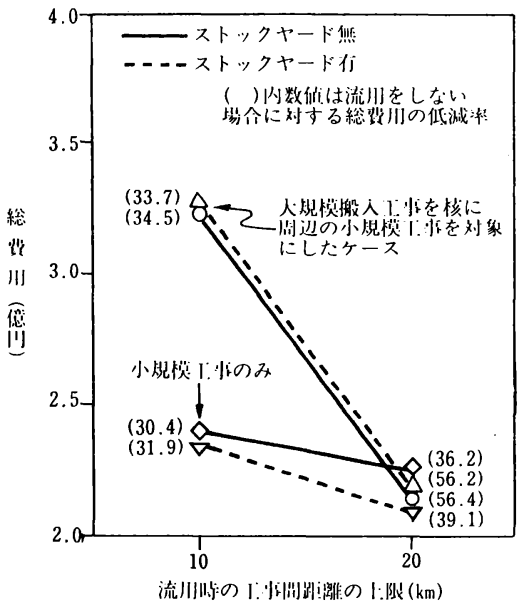

(a) 総监川

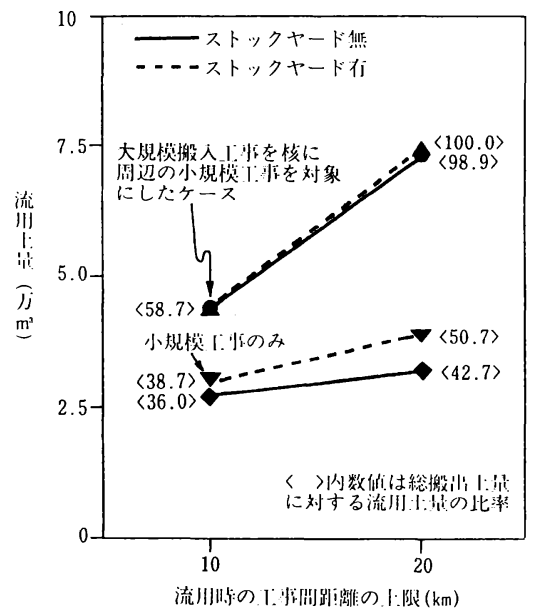

(b) 流间：昂

図一4 モデル I の適用結果

の事例ではほとんど差が認められない.これは大規模工 事の場合は一般に工期が長いために，ストックヤードを 経由して搬出・搬入時期の調整を行う必要性がほとんど 生じないためである.

また，費用関係のデータを現状值よりも 5 割高く見 積って本モデルを適用したところ, 全く流用しない場合 に対する総費用の低減率は現状費用のケースに比べて大 きくなっている．このことから，将来的に残土処理およ び土砂購入にかかわる費用がますます上昇するようであ れば，残土の流用はいっそう費用効果を高めるものにな るといえる。

ii ）大規模搬入工事を核に周辺の小規模工事を対象に したケース

土量調查リストの中から，搬入土量約 7 万 $\mathrm{m}^{3}$ の土地 造成工事を核として周辺 $20 \mathrm{~km}$ 圈内の小規模工事（搬 入土量 $1000 \mathrm{~m}^{3} \sim 1$ 万 $\mathrm{m}^{3}$ の工事 33 件, 総搬入土量 $85500 \mathrm{~m}^{3}$, 搬出土量 $1000 \mathrm{~m}^{3} \sim 3000 \mathrm{~m}^{3}$ の工事 41 件, 総 搬出土量 $74700 \mathrm{~m}^{3}$ ) を抽出し, 合計 75 件のデータに対 して本モデルの適用を試みた.

計算結果を図一4に示す，i ）のケースとは工事規模 が異なるので費用効果の大きさなどは異なっているが， 計算結果を総括すると，i）のケースと同様のことがい える.すなわち, 流用時の工事間距離の上限值を大きく して流用の対象となる工事の範囲を広くするほど多量の 流用が可能となり，それに伴って捨土処分量および土砂 購入量が減少し，総費用はかなり低減される．また，ス トックヤードの有無による差違をみると，この事例では 工期の長い大規模搬入工事亡工期の短い複数の小規模搬 出工事との間の流用が主体となっているため, 搬出・搬 入時期の調整のためのストックヤードを設けても効果の
少ないことがわかる.

iii）小規模工事を対象にしたケース

複数の小規模工事に対して本モデルを適用した場合の 例を示すために，ここではii ）で用いたデータの中から 大規模搬入工事だけを除いたケースを設定した. 計算結 果は図一4に示されている.

この事例で取り上げた小規模工事はいずれも工期が 2 〜 か月程度と短いため, 搬出 - 搬入時期の条件が適合 する工事の組合せは必然的に少なくなる.このため, 残 土を流用する場合の工事間距離の制約を緩めて流用可能 な工事の対象を広げても流用土量はあまり増えないこと が計算結果からわかる. 一方, 搬出・搬入時期のずれを 調整するためにストックヤードを設けると流用土量をか なり増やすことが可能となり, その結果として総費用も かなり低減できることがわかる．これはケースｉ），ii） にみられない特徴である.

\section{5. 工期調整を考慮した土量配分計画モデル (モデル II )}

\section{（1）モデル開発の背景}

4. に述べた土量配分計画モデルを適用するためには, 表一1に示した情報が正確に把握される必要がある.し かしながら，扱われる情報の多くは工事予定にかかわる ものであり, 種々の理由からこれらにある程度の不確実 性が存在してもやむを得ない場合が想定される. 本研究 では，公共土木工事を対象として調査された工事情報と 1 年後に追跡調査された各工事の土砂処分・調達の実績 を対比し, 工事着工前に収集された情報の不確実性の程 度を相対的, 定性的に評価した. 評価に用いたデー夕は, 関東地方 1 都 4 県を対象として調查された「土量調査り 


\section{表一 5 土量配分計画における入力情報の精度}

\begin{tabular}{|c|c|c|}
\hline 情報項目 & 計画時点で得られる情報の特性 & $\begin{array}{c}\text { 不確実性 } \\
\text { の程度 }\end{array}$ \\
\hline 工事場所 & 確定情報として得られる。 & 確定的 \\
\hline 土 量 & $\begin{array}{l}\text { 工事内容が確定していれば、土量は } \\
\text { ほぼ正確に把握されている。 }\end{array}$ & 小 \\
\hline 土 貭 & $\begin{array}{l}\text { 土貿調査が不十分なときは正確な把 } \\
\text { 握が難しいこともある。 }\end{array}$ & 小 \\
\hline $\begin{array}{c}\text { 土工開始 } \\
\text { 時期 }\end{array}$ & $\begin{array}{l}\text { 工事全体の進捗状況、気象条件など } \\
\text { の外的要因により当初計画から変更 } \\
\text { されることが多く、計画時点で確定 } \\
\text { 的な情報として得にくい。 }\end{array}$ & 大 \\
\hline 土工期間 & $\begin{array}{l}\text { 関連工種の進渉、気象、土質などの } \\
\text { 条件により当初計画から変更される } \\
\text { ことがある。 }\end{array}$ & 中 \\
\hline その他 & ほぼ正確に把挃でき & 確定 \\
\hline
\end{tabular}

スト」およびその追跡調查結果である. 表一 5 は評価の 結果をまとめたもので，表に示すように，土量配分計画 の立案に必要な工事情報のうち不確実性の程度が最も大 きいのは土工開始時期であると判断された。

以上に述べたような背景のもとで，本研究では各工事 の土工開始時期に関する情報に “あいまいさ”があるも のとし, 土量配分計画の立案時点において土工開始時期 の調整を同時に行うことを前提として，工期調整を考慮 した計画モデルを開発した。

（2）モデル化のための基本方針および前提条件

本モデルでは，ある時期の般出・搬入土量に関する制 約条件をモデル I のように「 $a\left(\mathrm{~m}^{3}\right)$ でなければならな い」という確定的な条件ではなく，「なるべく $a\left(\mathrm{~m}^{3}\right)$ にしたい」というあいまい（ファジィ：Fuzzy）な制約 条件として扱い，これによって土工時期に自由度をもた せることにした，一方，土量配分計画の最適性の評価基 準については，モデル I では土砂処分調達にかかわる総 費用の最小化を設定したが，本モデルでは「なるべく総 費用が安くなるように土量を配分したい」という“あい まいさ”のある満足度基準を設定することにした。

事象の “あいまいさ”を表現する手法として，ここで はファジィ集合を用いた。フファジィ集合はあいまいな境 界をもつ集合を意味し，個々の要素がその集合に属する 度合いを帰属度として表現するもので，この考え方を一 般の線形計画問題 (LP) に応用したのがファジィ線形 計画問題 (Fuzzy-LP と記す) である. Fuzzy-LP では, 制約と目標を区別することなく両方に“あいまいさ”を 考虑するのが特徵である ${ }^{4}$.

モデル化のための前提条件をまとめると以下のとおり である。

i ）複数の搬出・搬入工事間の合理的な土量配分問題 を考えるものとし，その際には個々の工事の全体工 期や工費に影響を及ぼさない範囲内で土工時期の調 整を認めるものとする.

ii）計画対象期間を $T$ 期に分割し，各期の配分土量 $X_{i j}^{t}(k)$ (第 $t$ 期に搬出工事 $i$ 只ら搬入工事 $j$ へ運
ばれる土質レベル $k$ の土量）を決定変数とする. なお，表記を簡略化するために，以下では土質レべ ルの表示を省略する.

iii）各工事の土工開始時期に関する情報が“あいまい” な場合を想定し（例：だいたい 8 月 1 日ごろ土工を 開始する), 土工開始時期に関する条件が満たされ る度合いを帰属度で表わす。

iv）各工事の土工開始時期を第 $t_{s}$ 期初日，土工終了 時期を第 $t_{e}$ 期末日としてデー夕入力するのを基本 とし, 工期調整によって前後 1 期以内の変更を認め るものとする．このとき，工事 $i に$ 関して「なるべ く第 $t_{s i}$ 期初日に搬出を開始したい」という条件を 「第 $t_{s i}$ 期の般出土量をだいたい $a_{i}$ にしたい」と いう土量条件に置き換える，いま，工期調整を認め ない場合の土量配分を図一5(a) のように考えると， その土量条件は,

$$
\sum_{j=1}^{n} X_{i j}^{t}=a_{i}^{t}, \quad \sum_{t=t_{s l}}^{t_{e l}} a_{i}^{t}=A_{i}, \quad a_{i}^{t}=\bar{a}_{i}
$$

(ここに, $A_{i}$ : 工事 $i$ の総搬出土量)

として表わされるのに対し，工期調整によって開始 遅れを認める場合には図一5(b) のような搬出土量 となり，このときの土量条件は式（2）で表わされ る.

$$
\left.\begin{array}{l}
\sum_{j=1}^{n} X_{i j}^{t}=a_{i}^{t}, \quad \sum_{t=t_{s t}}^{t_{e l t}+1} a_{i}^{t}=A_{i} \\
\bar{a}_{i}-\alpha_{i} \bar{a}_{i} \leqq a_{i}^{t_{s}} \leqq \bar{a}_{i} \\
a_{i}^{t}=\bar{a}_{i} \quad\left(t=t_{s i}+1, \cdots t_{e i}\right)
\end{array}\right)
$$

なお，ここでは問題を単純化するために，第 $t_{s i}$ 期 と第 $t_{e i}+1$ 期を除く各期の土工量 $a_{i}^{t}$ は各工事の平 均土工量 $\bar{a}_{i}$ に等しいものとしている。また，開始 遅れに伴う土工量変更の許容範囲を $\alpha_{i} \cdot \bar{a}_{i}$ としてい る.

$\mathrm{v} ）$ 土砂処分調達および運搬費用の総和 $Z$ が，ある 志望水準 $Z_{a}$ をあまり超えないようにする.

\section{（3）モデルの定式化}

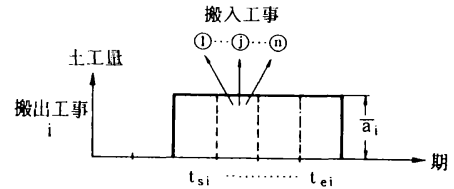

（a）關始遅れのない場合

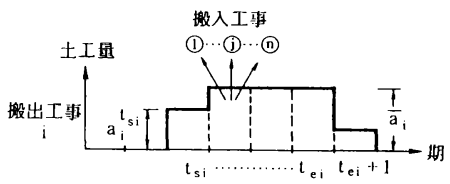

（b）工期諴整によって開始荤れがある場合

図一5 土工開始遅れを認める場合の土工貫の設定 
以上の条件を前提として土量配分計画問題を整理する と，「土量に関する制約条件の一部にあいまいな領域を 認めたうえで総費用をだいたい $Z_{a}$ 以下にしたい」とい う問題となりこれは式（3）で示されるような Fuzzy-LP として定式化される.

$$
\begin{aligned}
& A x \approx b \\
& C x \leqq Z_{a} \\
& x \geqq 0
\end{aligned}
$$

ここに, $\boldsymbol{A}$ : 係数行列, $\boldsymbol{x}$ : 変数ベクトル, $\boldsymbol{b}:$ 定数べ クトル, $C$ : 費用係数ベクトル (行ベクトル), $Z_{a}:$ 総 費用の志望水準,であり, こ は「だいたい等しくしたい」, ミは「あまり超えてはいけない」ことを表わす便宜的 な記号である.

この問題を解くにあたっては制約条件 (土量条件) と 目標（総費用）をファジィ集合として扱い，その帰属度 $\lambda$ を最大にするような代替案を選択する.すなわち, 個々 の帰属度のうち最小のものを最大にするという考え方を 基本とする.

次に，上記iv），v）に示したファジィな条件を定式 化するためには，何らかの帰属度関数を設定する必要が あるが，帰属度関数は制約条件および目標に対する計画 立案者の考え方が反映される部分でもあり，一義的な設 定法は存在し得ないものと思われる。ここでは，すべて の帰属度関数が線形の場合を考えると，Fuzzy-LP は以 下に示す通常の線形計画問題として定式化される.

(1) 搬出工事 $i$ について

土工期の遅れを認める場合，遅れに伴う土量の調 整許容範囲を $\alpha_{i} \cdot \bar{a}_{i}$ とし，第 $t_{s i}$ 期と第 $t_{e i}+1$ 期の 土量条件の帰属度関数を図一6に示すように設定す ると, 土量条件は式（4）で表わされる.

$$
\begin{aligned}
& \lambda \leqq 1+\frac{\sum_{j=1}^{n} X_{i j}^{t_{s i}}-\bar{a}_{i}}{\alpha_{i} \bar{a}_{i}} \\
& \sum_{j=1}^{n} X_{i j}^{t}=\bar{a}_{i} \quad\left(t=t_{s i}+1, \cdots \cdots, t_{e i}\right) \\
& \lambda \leqq 1-\frac{\sum_{j=1}^{n} X_{i j}^{t_{e i+1}}}{\alpha_{i} \bar{a}_{i}}
\end{aligned}
$$

なお，土工期の早まりを認める場合についても同 様の考え方で定式化ができ，さらに，土工期の早遅 を同時に考慮する場合には 0-1 型変数 $\delta_{i}$ (土工期 の遅れを認めるとき 1 ，そうでないとき0）を制約

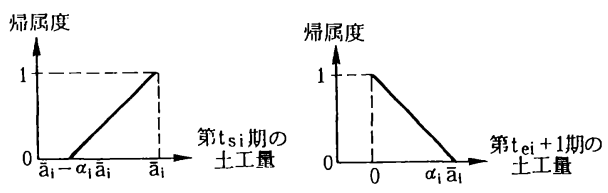

図一土每条件に関する帰属度関数

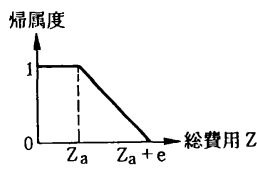

\section{図一7 総費用に関する帰属度関数}

条件式の中に組み込むことによって対処することが できる.

(2) 搬入工事 $j$ について

搬出工事の場合と同様なので,ここでは省略する。

（3）総費用について

総費用の志望水準 $Z_{a}$ および費用制約の許容範囲 $e$ を設定し，図一7に示すような㷌属度関数を仮定 することにより，次式のように定式化される.

$$
\left.\begin{array}{l}
\lambda \leqq 1-\frac{Z-Z_{a}}{e} \\
Z=\sum_{i=1}^{T} \sum_{i=1}^{m} \sum_{j=1}^{n} C_{i j} X_{i j}^{t}
\end{array}\right\}
$$

(4) 目的関数

$\lambda \rightarrow \operatorname{Max}$.

なお, 以上に示した定式化では, 搬出工事 $i$ には土取 場を，搬入工事 $j$ には捨土処分地を含んでいる.

\section{（4）適用事例}

一般に搬出・搬入土量が多い大規模工事では工事着手 のかなり以前に施工計画が明確にされているのに対し， 搬出・搬入土量の少ない小規模工事の場合には情報の入 手時点で土工開始時期に関する情報にあいまいさが含ま れる可能性が大きい，そこで，比較的小規模な工事の集 合に対して本モデルの適用を試みることとし, 工事場所, 搬出・搬入土量，土質，運搬費用などのデータは4.（2） iii）でモデル I を適用した事例と同一のものを用いた。 なお，計画対象期間の分割単位は 1 か月とした.

本事例計算では，土工開始時期に関する情報のあいま いさが土量配分結果に及ぼす影響をみるために，開始期 における土工量の調整許容範囲 $\alpha_{i}$ を種々設定して計算 を行い，工期調整を行わずに土量配分を行った場合（モ デルＩ）との比較を行った.ただし， $\alpha_{l}$ は全工事に共 通の值を使用した。また，総費用の志望水準 $Z_{a}$ はモデ ル I の解 $Z_{0}(=234208$ 千円）を基準值にして,

$$
Z_{a}=Z_{0}-e=(1-\beta) Z_{0}
$$

として設定することとし， $\beta$ をパラメーターとして以下 の計算を行った.

図一8 は， $\alpha_{i}$ を $100 \%$ に固定し, $\beta$ を $10 \%, 20 \%, 30 \%$, $40 \%, 50 \%$ の 5 段階に設定して計算を行った結果を示 したものである. 図からわかるように，工期調整を考慮 に入れることによってモデル I に比べて総費用の低減化 および流用土量の増大化をいっそう図ることができる. 


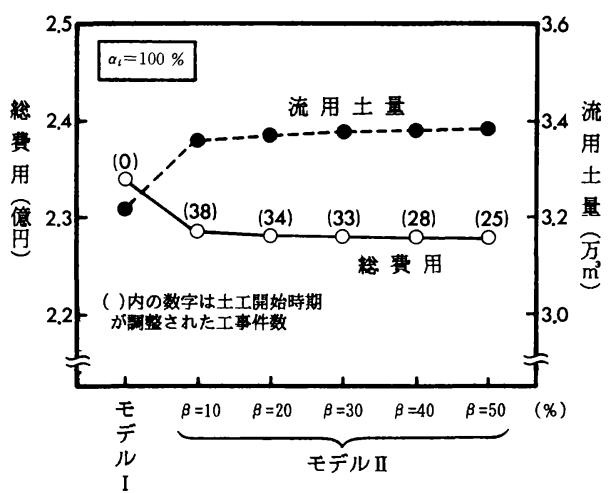

図一8 モデル Пの適用結果 $\left(\alpha_{l}\right.$ 一定 $)$

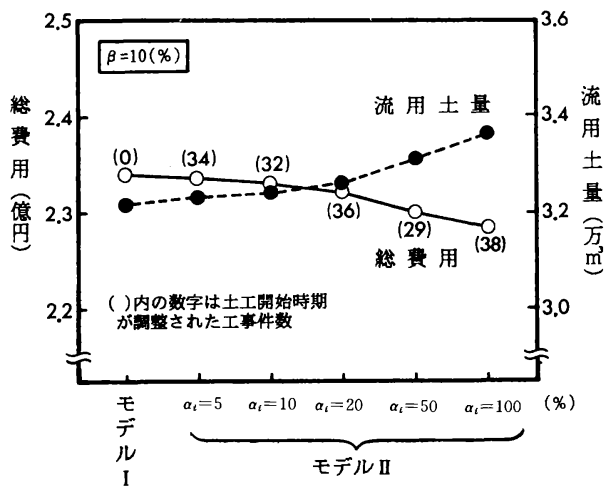

図一9 モデル Пの適用結果 $(\beta$ 一定)

ただし，この事例では $\beta$ に対する感度は鈍く，総費用 の志望水準 $Z_{a}$ の設定が解に与える影響は少ないといえ る.

一方, $\beta$ を $10 \%$ に固定し, $\alpha_{i}$ を $5 \%, 10 \%, 20 \%, 50 \%$, $100 \%$ の 5 段階に設定して計算を行った結果を図一 9 に 示す．総費用はいずれのケースともモデル I より小さい 值が得られており, 工期調整による費用低減効果が表わ れている. また， $\alpha_{i}$ の值が大きいほど工期調整の効果 が大きいことがわかる．たとえば，工期調整の範囲を最 も大きく設定した場合 $\left(\alpha_{i}=100 \%\right)$ ，モデル I に比べて 総費用は $2.5 \%$ 低減され, 流用土量は $4.5 \%$ 多くなって いる.この計算結果より, 本モデルが有効に機能してい るといえよう。

\section{6. 搬出・搬入工事の最適組合せモデル (モデルIII )}

\section{（1）モデル開発の背景}

4. では土量配分計画の立案に必要な入力情報が確定 的に与えられる場合の計画モデルを提案し，5. では土 工開始時期に関する情報にあいまいさがあることを前提 に工期調整を考慮した計画モデルを提案した。これら 2
つのモデルに共通しているのは配分土量 $X_{i j}^{t}(k)$ を決定 変数としている点である. ところが現実の搬出・搬入工 事の実施状況をみると，5.（1）でも述べたように，土 工開始時期が当初予定と異なるケースがしばしば生じて おり，このような場合に $X_{i j}^{t}(k)$ を決定変数として土量 配分計画を立案しておくと個々の工事の施工計画に変更 があった場合に対処しづらくなるおそれがある.

そこで, 本研究では 1 つの搬出工事からの残土受け入 れ先としての般入工事を 1 工事のみに限定し，それらの 最適な組合せを求めるモデルを考えた. 本モデルは, 個々 の工事の施工計画がまだ十分に明確になっていない時点 で土量配分計画を立案することを前提としており，この モデルによって最適な組合せと認められた搬出・搬入工 事のペアは，工事実施の時点で各時期の搬出・搬入土量 といった詳細な配分内容を検討することになる．このよ うに搬出・搬入工事の最適な組合せのみを求めておき, その後に個々の工事の施工計画の変更が生じても当事者 間の調整で対処しようとするのが本モデルの根底にある 考え方である。

\section{（2）モデル化のための前提条件と定式化}

モデル化にあたっての前提条件は以下のとおりであ る.

i ）本モデルは同程度の搬出・搬入土量をもつ工事の 集合に対して適用するものとし，当該工事から搬出 される残土の流用先（搬入工事）は 1 工事のみとす る．大規模工事が含まれる場合には，これを適当な 数の工事に分割することによって工事規模のレベル を合わせるものとする.

ii）最適性の評価基準として期待総費用の最小化を考 える.

iii）入力情報のうち，各工事の土工開始時期について は確率分布として与えるものとする。

iv）土質条件の考え方および計画対象期間の分割の考 え方はモデル I， モデル II と同様とする．ただし， ここでは土質改良プラントおよびストックヤードは 考慮に入れてない.

v）搬出工事・搬入工事ともそれぞれの土工期間内に おいて各期の土工量は等しいものとする.このよう な前提条件を設けたのは，土工開始時期の不確実性 を考慮するような計画問題では, 個々の工事の期ご との土工量に関する情報を十分な精度で入手するこ とが困難と考えられるためである。なお，前述した 「土量調查リスト」およびその追跡調查結果をもと に各工事の土工量の時系列的変動を調べたところ， 全体的に有意な傾向は認められず，一般に土工量は 期間内でほぼ平均しているという結果が得られた. したがって，この前提条件はおおむね妥当なものと 


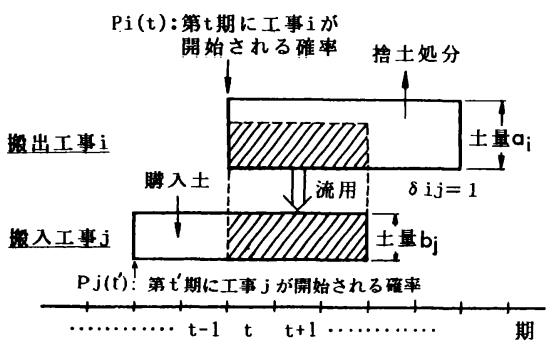

図一10 費用係数算出における土砂処分調達の考え方

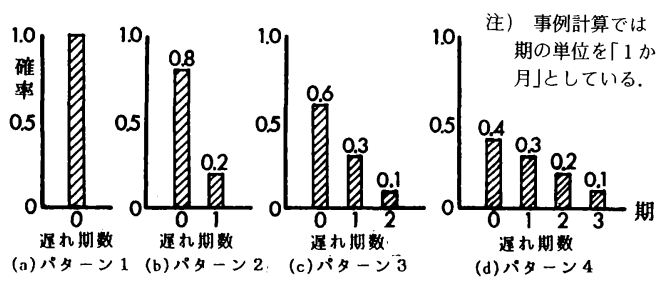

図一11 土工開始時期の遅れの確率パターン

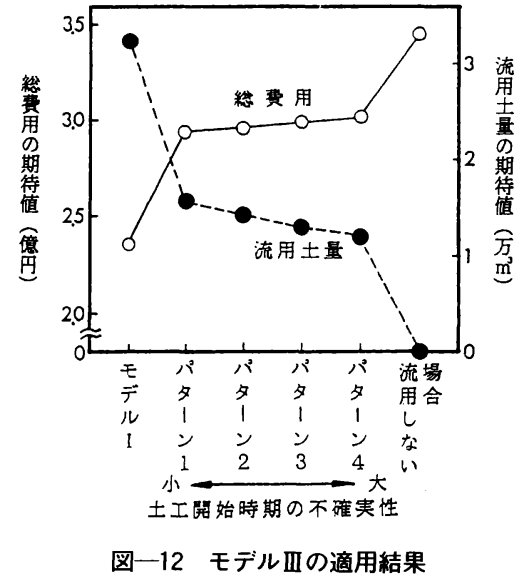

いえる.

以上の前提条件のもとで，土量配分計画モデルを次に 示す “割当て問題” 型の線形計画問題として定式化した.

$Z=\sum_{i=1}^{m} \sum_{j=1}^{n} C_{i j} \cdot \delta_{i j} \rightarrow$ Min.

$\sum_{i=1}^{m} \delta_{i j}=1, \sum_{j=1}^{n} \delta_{i j}=1$

$\delta_{i j}=0$ or 1

ここに, $C_{i j}$ : 搬出工事 $i$ と搬入工事 $j$ との間で流用 を行う場合の費用の期待值 (定数),$Z$ : 総費用の期待 值 (目的関数)， $\delta_{i j}$ : 搬出工事 $i$ と搬入工事 $j$ との間て 流用を行うとき 1 ，そうでないとき 0 とする変数，であ る. $C_{i j}$ は, 搬出工事 $i$ と搬入工事 $j$ の組合せごとに図 一10に示すように流用土量, 捨土処分土量, 購入土量 を求め,これらにそれぞれの単価亡工事 $i, j$ の開始時
期の確率を乗じることによって求められる．たとえば, 図一10 の上うに搬入工事 $j$ の開始時期 $t^{\prime}$ が搬出工事 $i$ の開始時期 $t$ より常に早く, かつ土量が $a_{i}>b_{j}$ となっ ている場合には， $C_{i j}$ は次式で求められる.

$$
\begin{aligned}
C_{i j}= & \sum_{t} \sum_{t} P_{i}(t) \cdot P_{j}\left(t^{\prime}\right)\left[C B_{j} \cdot b_{j}\left(t-t^{\prime}\right)\right. \\
& +C D_{i}\left\{\left(a_{i}-b_{j}\right)\left(t^{\prime}+T_{j}-t\right)+a_{i}\left(t+T_{i}-t^{\prime}-T_{j}\right)\right\} \\
& \left.+C R_{i j} \cdot b_{j}\left(t^{\prime}+T_{j}-t\right)\right] \cdots \cdots \cdots \cdots \cdots \cdots \cdots \cdots \cdots \cdots \cdots \cdots \cdots \cdots \cdots \cdots \cdots(10)
\end{aligned}
$$

ここに, $C D_{i}$ : 搬出工事 $i$ から捨土処分する土の処分単 価, $C B_{j}$ : 搬入工事 $j$ で購入する土の購入単価, $C R_{i j}$ : 搬出工事 $i$ から搬入工事 $j$ へ流用する土の運搬単価, $T_{i}, T_{j}$ : 工事 $i$ および $j$ の工期，である.

\section{（3）適用事例}

一般に小規模工事ほど土工開始時期に関する情報に不 確実性を伴う可能性が高く, 本モデルの適用に向いてい ると考えられる. そこで，ここでは小規模工事の集合を 計算の対象として取り上げることとし，4. ( 2 ) iii) お よび5. (4 ) でモデル I, モデル】を適用したのと同一 の事例（搬入工事 33 件, 総搬入土量 $85500 \mathrm{~m}^{3}$, 搬出工 事 41 件, 総搬出土量 $74700 \mathrm{~m}^{3}$ ) に対して本モデルを適 用した. 費用関係等のデータもこれまでと同一のものを 使用した.

ここでは土工開始時期の確率分布の違いが搬出・搬入 工事の組合せにどの程度の影響を及ぼすかを調べるため に, 土工開始時期が確定的に与えられる場合（パターン 1）と図一11に示すように土工開始時期の遅れが確率 的に与えられる場合（パターン $2,3,4)$ について計算 を行い (パターンは全工事に共通), さらに比較のため にモデルIによる計算も行った.

図一12 に事例計算結果を示す。本モデルは工事単位 で残土の流用先を決定するため, 当然のことながらモデ ル I に比べて流用土量は少なく, 総費用が高い結果とな るものの, 所期の目的にかなう結果が得られた. 次に, 土工開始時期の確率パターン $1 \sim 4$ を用いて本モデルを 適用した結果を比較すると，パターン 1 の場合に総費用 の期待値が最も小さく, 全く流用しない場合に比べて約 5 千万円の費用節減が期待できることがわかる．また， 遅れる期数が多くなるほよ゙，すなわち土工開始時期の確 定度が低くなるほど総流用土量の期待值は減少し, 総費 用の期待值は増加する傾向にあるという結果が得られ た。

なお，本事例では土工開始時期の確率パターンごとに 図一13に示すような 11〜12 件の組合せが最適解として 出力され, 組合せ結果はパターンによって若干異なるも のであった. したがって, 確率パターンは計画上の重要 な因子と考えられるが，本事例の結果をみる限りにおい ては総流用土量や総費用の期待值にはあまり大きな影響 
搬出工事

○搬入工事

注）図中数字は工事 番号を表す。

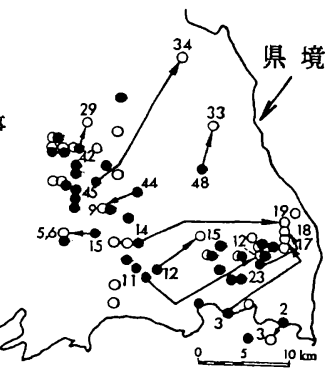

(a) パターン 1

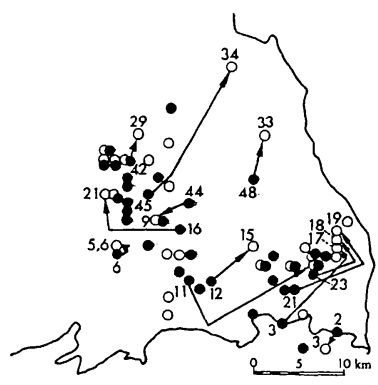

(c) パターン 3

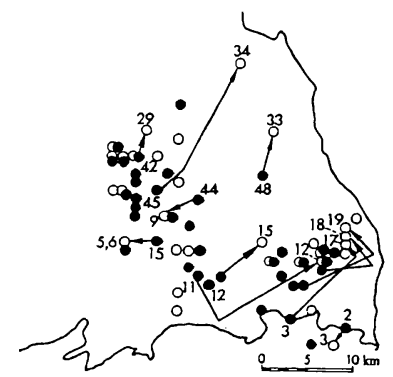

(b) パターン 2

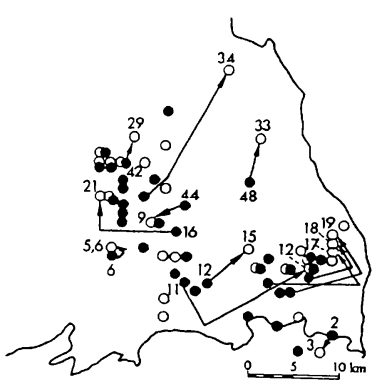

(d) パターン 4

図一13 モデル吕の適用結果（搬出・搬入工事の組合せ）

を与えないことがわかる.

\section{7.おわりに}

年々深刻化しつつある建設残土問題に対処するための 施策の 1 つとして, 複数工事間での残土の積極的な流用 の必要性が強く認識されており，本論文では合理的な流 用を行うための計画モデルの提案を行った。 その概要を まとめると以下のとおりである.

（1）すべての入力情報が確定量として得られる場合 を想定し，線形計画法を用いた計画モデル (モデル I ) を提案した. また, 本モデルが有効に機能することを事 例計算によって示した。

（2）土量配分計画の立案時点において各工事の土工 時期を調整することを前提とした計画モデル(モデル II ) を提案した。このモデルでは土工開始時期の条件と総費 用の目標に“あいまいさ”があるものとしてファジィ線 形計画法を用いている. 事例計算を通して, 工期調整を 考慮することによってモデル I よりも費用低減された計 画が立案できることを示した。

（3）入力情報に不確定要素が多く含まれる場合に は, 詳細な土量配分計画を立案するよりも搬出工事と搬 入工事の最適な組合せを求めておくことが重要と考え, そのための割当て問題型の計画モデル（モデルIII）を提
案した。また，事例計算によっ て所期の目的にかなった解が得 られることを示した。

本論文で提案したような計画 モデルを実際の問題に適用する 場合, 出力結果の信頼性はモデ ルに入力される工事情報の精度 に大きく依存する.したがって， 計画対象期間内に実施される搬 出・搬入工事の情報がどの程度 の確からしさで収集され得るか が重要な課題となる．現行の体 制では精度の高い情報収集はま だ困難かもしれないが，残土問 題がさらに深刻化するようであ れば，工事情報の収集体制の改 善についての検討も必要になっ てこよう.

謝 辞 : 本研究の成果の一 部は，建設省総合技術開発プロ ジェクト「建設事業への廃棄物 利用技術の開発」の研究成果の一部であり ${ }^{5)}$, 貴重なご 意見ならびにデータの提供をいただいた関係各位に感謝 する次第である．また，本論文をまとめるにあたっては， 名古屋工業大学 山本幸司 助教授に貴重なご助言をいた だくとともに，建設省土木研究所下坪賢一氏には多大 なご助力をいただいた．記して深謝の意を表する次第で ある。

\section{参 考 文 献}

1）浅川美利：現場発生土の有効利用，土と基礎，第 29 巻, 第 11 号, 土質工学会, pp. 9 12, 1981 年 11 月.

2）新藤範義：建設残土処理対策の課題一首都圈における処 理実態と将来展望一, 土木学会関東支部講習会「建設廃 棄物に関する問題」, 土木学会関東支部, pp. $23 \sim 35$, 1985 年 3 月.

3）見波 潔・嶋津晃臣・下坪賢一：道路占用工事における 残土処理計画, 土木計画学・講演集 8 , 土木学会, pp. $537 \sim 543,1986$ 年 1 月.

4）西田俊夫・竹田英二：ファジィ集合とその応用，森北出 版, 1978 年 11 月.

5）建設省：建設事業への廃棄物利用技術の開発報告書, 1986 年 3 月。

(1987.10.2 • 受付) 